\title{
NADGIŚNIENIE TETNIGZE
}

Redaktor działu: prof. dr hab. n. med. Krzysztof Narkiewicz

\section{Nadciśnienie tętnicze maskowane niedoceniany problem}

\author{
Masked hypertension - underestimated problem
}

\section{Martyna Liśkiewicz-Jankowska, Marzena Chrostowska}

Klinika Nadciśnienia Tętniczego i Diabetologii Gdańskiego Uniwersytetu Medycznego

\section{STRESZCZENIE}

Nadciśnienie tętnicze maskowane (MH) rozpoznaje się u pacjentów dotychczas nieleczonych, u których ciśnienie tętnicze w gabinecie jest prawidłowe, czyli poniżej 140/90 mm Hg, a w pomiarach pozagabinetowych jest podwyższone — zatem średnie ciśnienie tętnicze w pomiarach domowych (HBPM) i/lub w calodobowej rejestracji ciśnienia tętniczego (ABPM) w ciągu dnia wynosi co najmniej $135 / 85 \mathrm{~mm} \mathrm{Hg}$ albo w czasie snu nie mniej niż 120/70 mm Hg. Wykonanie pozagabinetowych pomiarów ciśnienia jest warunkiem sine qua non rozpoznania $\mathrm{MH}$. Szacuje się, że MH dotyczy nawet $30 \%$ osób z prawidłowym ciśnieniem w gabinecie lekarskim. Należy go aktywnie poszukiwać u wszystkich pacjentów z wysokim prawidłowym ciśnieniem. Nadciśnienie tętnicze maskowane częściej występuje u mężczyzn w średnim wieku, z wysokim prawidłowym ciśnieniem, palących tytoń, spożywających w większych ilościach alkohol lub inne używki, narażonych na stres. Choroby predysponujące do wystąpienia MH to: otyłość, cukrzyca, przewlekła choroba nerek, obturacyjny bezdech senny. Szczególną postacią MH obciążającą układ sercowo-naczyniowy jest wysokie ciśnienie tętnicze w czasie snu i brak nocnego spadku ciśnienia tętniczego. U pacjentów z nadciśnieniem tętniczym maskowanym globalne ryzyko sercowo-naczyniowe jest znamiennie wyższe w porównaniu z osobami normotensyjnymi. Ze względu na częste występowanie powikłań narządowych i chorób współistniejących są to zazwyczaj pacjenci wysokiego ryzyka. Szacuje się, że u ponad $35 \%$ chorych z $\mathrm{MH}$ rozwinie się utrwalone nadciśnienie tętnicze. Jeden na pięciu pacjentów przez wiele lat będzie miał podwyższone wartości ciśnienia tętniczego jedynie w pomiarach pozagabinetowych, co potencjalnie opóźni diagnozę i leczenie, a jednocześnie rozwój subklinicznych powikłań narządowych będzie postępował. Dlatego też leczenie niefarmakologiczne i farmakologiczne powinno być wdrożone u wszystkich pacjentów z rozpoznanym nadciśnieniem maskowanym. Zgodnie z aktualnymi wytycznymi European Society of Hypertension/European Society of Cardiology należy aktywnie poszukiwać MH, zaś ABPM i HBPM powinny być podstawowym elementem diagnostyki i kontroli efektów terapii nadciśnienia maskowanego.

Choroby Serca i Naczyń 2019, 16 (1), 17-23

Słowa kluczowe: nadciśnienie maskowane, częstość występowania, powikłania, leczenie

\section{ABSTRACT}

Masked hypertension should be defined in untreated patients, who have normal office blood pressure < 140/ /90 mm Hg, with elevated out-of-office average levels in home blood pressure measurement (HBPM) 
or/and ambulatory blood pressure monitoring (ABPM) with a daytime $B P \geq 135 / 85 \mathrm{~mm} \mathrm{Hg}$ or nighttime $B P \geq$ $120 / 70 \mathrm{~mm}$ Hg. Performing out-of-office blood pressure measurements is a sine qua non condition for MH diagnosis. Masked hypertension can be found in even $30 \%$ of patients with a normal office blood pressure. To detect this type of hypertension, patients with high-normal BP, should be regularly controlled. The prevalence is greater in middle age men, with high-normal BP, smokers, abusing alcohol or other drugs and with higher levels of stress. Obesity, diabetes, chronic kidney disease, obstructive sleep apnea are also associated with an increased prevalence of masked hypertension. A special form of masked hypertension, associated with increased risk of hypertensive target organ damage (HMOD), is nocturnal hypertension and non-dipping. The risk of cardiovascular events is substantially greater in masked hypertension, compared with normotension. Because of frequent occurrence
HMOD and comorbidities in population with $\mathrm{MH}$, they are usually high-risk patients. It was estimated, that over $35 \%$ in individuals with masked hypertension, will develop persistence hypertension. But one in five patients, in long-term observation, will have only out-of-office elevated blood pressure, which potentially delays diagnosis and treatment, with the progressive development of HMOD. Therefore, in masked hypertension lifestyle changes and antihypertensive drug treatment are recommended. According to European Society of Hypertension/European Society of Cardiology guidelines, ABPM or HBPM is specifically recommended for clinical indications, such as identifying and control of antihypertensive treatment effect in masked hypertension.

Choroby Serca i Naczyń 2019, 16 (1), 17-23

Key words: masked hypertension, prevalence, target organ damage, treatment

\section{WPROWADZENIE}

Nadciśnienie tętnicze od wielu dekad jest głównym czynnikiem ryzyka chorób sercowo-naczyniowych na świecie. Właściwa kontrola ciśnienia tętniczego przyczynia się do zmniejszenia ryzyka wystąpienia powikłań tej choroby, takich jak zawał serca, udar czy przewlekła choroba nerek oraz zgonów z ich powodu. Ryzyko powstania powikłań rośnie liniowo wraz ze wzrostem ciśnienia tętniczego już powyżej $115 \mathrm{~mm} \mathrm{Hg}$ ciśnienia skurczowego (SBP, systolic blood pressure) i $70 \mathrm{~mm} \mathrm{Hg}$ ciśnienia rozkurczowego (DBP, diastolic blood pressure). Stąd wartość, powyżej której rozpoznaje się nadciśnienie tętnicze, wyznacza się arbitralnie [1]. Definicja nadciśnienia tętniczego pozostaje niezmienna od wielu dekad. Klasycznie nadciśnienie tętnicze rozpoznaje się na podstawie pomiarów w gabinecie lekarskim (OBPM, office blood pressure), gdy ciśnienie tętnicze wynosi powyżej 140 i/lub 90 mm Hg.
Jednak od czasu wprowadzenia na szeroką skalę do praktyki klinicznej pomiarów pozagabinetowych rozpoznanie nadciśnienia tętniczego stało się możliwe nie tylko na podstawie OBPM, ale również przy użyciu całodobowej rejestracji ciśnienia tętniczego (ABPM, ambulatory blood pressure measurement) i pomiarów domowych (HBPM, home blood pressure measurement). Co więcej, istnieją dowody z badań prospektywnych, że ABPM i HBPM lepiej korelują z powikłaniami nadciśnienia tętniczego niż pomiary gabinetowe $[2,3]$.

\section{ROZPOZNANIE, DEFINICJA, DIAGNOSTYKA}

Zaobserwowano, że wartości ciśnienia tętniczego $\mathrm{w}$ gabinecie nie zawsze są spójne z wartościami ciśnień $\mathrm{w}$ pomiarach pozagabinetowych. Gdy porównano ciśnienia w gabinecie i poza nim, okazało się, że oprócz utrwalonego nadciśnienia tętniczego mogą występować też stany pośred- nie, które nie są już normotensją, ale nie są one też utrwalonym nadciśnieniem tętniczym (tab. 1). Tak więc, gdy na podstawie ciśnienia $\mathrm{w}$ gabinecie rozpoznaje się nadciśnienie tętnicze, a $\mathrm{w}$ pomiarach pozagabinetowych jest ono prawidłowe, mowa o nadciśnieniu białego fartucha ( $\mathrm{WCH}$, white coat hypertension), w odwrotnej sytuacji zaś - gdy ciśnienie $\mathrm{w}$ gabinecie jest prawidłowe, a w ABPM $\mathrm{i} / \mathrm{lub} \mathrm{w}$ pomiarach domowych spełnia kryteria rozpoznania nadciśnienia tętniczego - mowa o nadciśnieniu tętniczym maskowanym $(\mathrm{MH}$, masked hypertension). Jeśli kryteria te spełniają pacjenci z rozpoznanym wcześniej nadciśnieniem tętniczym, leczeni hipotensyjnie, to diagnozuje się, odpowiednio: zespół białego fartucha (WCS, white coat syndrom) lub źle kontrolowane nadciśnienie tętnicze maskowane (MUCH, masked uncontrolled hypertension) [4]. Dlatego jednym z podstawowych wskazań do pomiarów pozagabinetowych jest 
Tabela 1. Rozpoznanie nadciśnienia tętniczego, nadciśnienia białego fartucha i nadciśnienia maskowanego na podstawie gabinetowego i pozagabinetowych pomiarów ciśnienia tętniczego

\begin{tabular}{|c|c|c|}
\hline \multirow[t]{2}{*}{ Pomiar w gabinecie [mm Hg] } & \multicolumn{2}{|c|}{ Pomiary pozagabinetowe: HBPM i ABPM [mm Hg] } \\
\hline & $\begin{array}{c}\text { Dzień }<135 / 85 \\
\text { Noc }<120 / 70\end{array}$ & $\begin{array}{c}\text { Dzień > 135/85 } \\
\text { Noc > 120/70 }\end{array}$ \\
\hline $\mathrm{BP}<140 / 90$ & Normotensja & Nadciśnienie maskowane \\
\hline $\mathrm{BP}>140 / 90$ & Nadciśnienie „białego fartucha” & Nadciśnienie tętnicze utrwalone \\
\hline
\end{tabular}

diagnostyka wymienionych fenotypów nadciśnienia tętniczego, co znalazło odzwierciedlenia w wytycznych zarówno polskich, jak i europejskich $[1,5]$.

Nadciśnienia tętniczego maskowanego nie można zdiagnozować tylko na podstawie pomiarów gabinetowych albo pozagabinetowych, niezbędne jest porównanie tych dwóch metod pomiaru. Jak już wspomniano, $\mathrm{MH}$ rozpoznaje się $\mathrm{u}$ dotychczas nieleczonych pacjentów, u których ciśnienie tętnicze w gabinecie jest prawidłowe, czyli poniżej 140/90 mm Hg, a średnie ciśnienie tętnicze w HBPM i/lub w ABPM w ciągu dnia wynosi co najmniej 135/85 mm Hg albo w czasie snu nie mniej niż 120/70 mm Hg [6]. Zarówno nazwę, jak i opis fenomenu MH pierwszy raz sformułował Pickering w 2002 roku.

\section{CZĘSTOŚĆ WYSTĘPOWANIA}

Nadciśnienie tętnicze maskowane występuje u 15-30\% dorosłych z prawidłowym ciśnieniem tętniczym w pomiarach gabinetowych [2, 7], może więc ono dotyczyć nawet jednego na trzech pacjentów z prawidłową kontrolą ciśnienia tętniczego w gabinecie lekarskim. Wśród osób normotensyjnych te z wysokim prawidłowym ciśnieniem są szczególnie predysponowane do wystąpienia MH. W wytycznych Europejskiego Towarzystwa Nadciśnienia Tętniczego (ESH, European Society of Hypertension) i Europejskiego Towarzystwa Kardiologicznego (ESC, European Society of Cardiology) z 2018 roku zleca się, aby wykonać pozagabinetowe pomiary ciśnienia tętniczego, zwłaszcza ABPM, u wszystkich pacjentów z wysokim prawidłowym ciśnieniem w celu oceny, czy nie występuje u nich $\mathrm{MH}$. Jest to niezwykle istotne, MH bowiem wiąże się z podwyższonym ryzykiem chorobowości i śmiertelności z powodu chorób sercowo- naczyniowych [8]. Ryzyko wystąpienia chorób układu krążenia jest co najmniej 2-krotnie wyższe niż u osób normotensyjnych, a porównywalne z tym u osób z utrwalonym nadciśnieniem tętniczym [9].

\section{U KOGO POSZUKIWAĆ NADCIŚNIENIA MASKOWANEGO?}

Wpływ na wystąpienie MH mają zarówno czynniki środowiskowe, jak i choroby współistniejące, takie jak otyłość, cukrzyca, przewlekła choroba nerek (CKD, chronic kidney disease) czy obturacyjny bezdech senny (OSA, obstructive sleep apnea). Nadciśnienie tętnicze maskowane częściej występuje u mężczyzn w średnim wieku, z ciśnieniem wysokim prawidłowym, palących tytoń, spożywających w większych ilościach alkohol lub inne używki. Wśród czynników ryzyka wymienia się również: dodatni wywiad rodzinny w kierunku nadciśnienia tętniczego, niski poziom edukacji, podatność na przewlekły stres $[1,10]$. Przy aktywnym poszukiwaniu MH należy zwrócić baczną uwagę na pacjentów z powikłaniami narządowymi lub wysokim ryzykiem sercowo-naczyniowym, u których gabinetowe pomiary ciśnienia są prawidłowe [11].

\section{CHOROBY PREDYSPONUJĄCE DO WYSTAPPIENIA NADCIŚNIENIA MASKOWANEGO}

Otyłość jest chorobą, w której częściej niż w populacji ogólnej występuje nadciśnienie maskowane, zwłaszcza w otyłości typu brzusznego (obwód pasa $>88 \mathrm{~cm}$ u kobiet, $>102 \mathrm{~cm}$ u mężczyzn). Wisceralna tkanka tłuszczowa jest aktywna hormonalnie i wydziela substancje metabolicznie czynne, takie jak leptyna, rezystyna, angiotensynogen, inhibitor aktywatora plazminogenu 1 (PAI-1, plasminogen activator inhibitor 1 ), czynnik martwicy nowotworów alfa (TNF- $\alpha$, tumor necrosis factor $\alpha$ ), interleukina 6 czy białko C-reaktywne (CRP, C-reactive protein), co prowadzi do szybszego ujawnienia się chorób, które są czynnikami ryzyka sercowo-naczyniowego, na przykład cukrzycy, hiperlipidemii, OSA. Jak wykazali w badaniach Grassi i wsp. [12], u otyłych pacjentów dochodzi do wzmożonej aktywności układu współczulnego, większej zmienności dobowej ciśnienia tętniczego [13], co w połączeniu z aktywnością hormonalną tkanki tłuszczowej prowadzi do rozwoju 
nadciśnienia tętniczego - na początku maskowanego, a z czasem utrwalonego.

Szczególną postacią MH jest $\mathrm{MH}$ z wysokim ciśnieniem w godzinach nocnych. Na podstawie analizy danych, pochodzących z prospektywnego kohortowego badania Jackson Heart Study, stwierdzono, że MH w ciągu nocy jest najczęstszym typem $\mathrm{MH}$ i dotyczy, odpowiednio: $53,6 \%$ chorych wśród pacjentów leczonych hipotensyjnie i 41,7\% wśród osób dotychczas nieleczonych. Mniejszy udział procentowy mają, odpowiednio: $\mathrm{MH}$ w ciągu całej doby i $\mathrm{MH}$ w ciągu dnia [2]. W badaniu PAMELA (Pressione Arteriose Monitorate E Loro Associazioni), zaobserwowano, że bezwzględne wartości ciśnienia tętniczego w nocy mają większą wartość prognostyczną niż ciśnienie w okresie czuwania. Wyższa wartość SBP o $10 \mathrm{~mm} \mathrm{Hg} \mathrm{w} \mathrm{nocy} \mathrm{wiązała} \mathrm{się} \mathrm{ze}$ znacznie większym wzrostem ryzyka zgonu z przyczyn sercowo-naczyniowych w stosunku do analogicznych wartości w czasie dnia [3]. Do nadciśnienia maskowanego z wysokimi wartościami ciśnienia $\mathrm{w}$ nocy są szczególnie predysponowani pacjenci ze współistniejącą cukrzycą, CKD, zespołem metabolicznym, OSA czy deprywacją snu [14].

Nadciśnienie tętnicze występuje u 2/3 chorych na cukrzycę typu 2 . Podwyższone wartości ciśnienia w tej grupie wiążą się z 72-procentowym wzrostem ryzyka dla wszystkich przyczyn zgonów i 57-procentowym wzrostem w przypadku ryzyka zgonu z powodów zdarzeń sercowo-naczyniowych [15]. Współistnienie nadciśnienia tętniczego u pacjentów z cukrzycą zwiększa obciążenie układu krążenia, mają oni zawsze wysokie lub bardzo wysokie ryzyko sercowo-naczyniowe. Dlatego dobra kontrola ciśnienia tęt- niczego to - oprócz kontroli glikemii - podstawowy cel leczenia pacjentów z cukrzycą. Nadciśnienie tętnicze maskowane występuje zarówno u pacjentów z cukrzycą dotychczas nieleczonych hipotensyjnie, u których może dotyczyć $29,3 \%$, jak i w grupie pacjentów z włączonym leczeniem hipotensyjnym, u których odsetek MUCH może sięgać 49,5\% [11]. Jak już wspomniano, cukrzyca jest jednym z czynników ryzyka MH z wysokimi wartościami ciśnienia w nocy.

W badaniu IDACO (International Database on Ambulatory Blood Pressure in Relation to Cardiovascular Outcomes), obejmującym 9691 chorych z MH z 11 krajów, wykazano, że MH niesie za sobą porównywalne ryzyko sercowo-naczyniowe do nadciśnienia tętniczego utrwalonego I stopnia. Stąd konieczne jest aktywne poszukiwanie $\mathrm{MH}$ u chorych na cukrzycę [11]. Zależność ta w kontekście współwystępowania nadciśnienia tętniczego i cukrzycy działa również w drugą stronę. Podczas 10-letniej obserwacji w grupie 1412 chorych z MH kontrolowano również glikemię na czczo. Na podstawie uzyskanych wyników dowiedziono, że MHwiąże się z długoterminową progresją zaburzeń gospodarki węglowodanowej i zwiększonym ryzykiem rozwoju cukrzycy w przyszłości [16]. W związku z tym - ze względu na większą częstość występowania $\mathrm{MH}$ w grupie chorych na cukrzycę w stosunku do populacji ogólnej — należy pamiętać o szczególnie ważnej roli pozagabinetowych pomiarów ciśnienia w tej grupie pacjentów.

Podwyższone wartości ciśnienia tętniczego w ciągu nocy są kluczowym problemem w przypadku kolejnego czynnika ryzyka $\mathrm{MH}$, jakim jest OSA. Powiązany z otyłością OSA często współistnieje z cukrzycą, jest niekwestionowanym czynnikiem ry- zyka nadciśnienia tętniczego i innych chorób układu krążenia. Jakjuż wspomniano, u chorych z OSA problemem jest nieprawidłowy profil dobowy ciśnienia, stąd konieczność wykonania ABPM w celu oceny ciśnienia tętniczego w nocy. W grupie pacjentów z OSA i wartościami ciśnienia tętniczego, spełniającymi kryterium rozpoznania nadciśnienia tętniczego, niezbędne są jednoczasowa farmakoterapia hipotensyjna i leczenie bezdechu [17]. Wykazano również istotny związek między OSA a HM - u pacjentów z OSA występuje ono częściej niż w populacji ogólnej i jest w dużej mierze niedoszacowane [18, 19]. Należy szczególnie podkreślić, że u chorych normotensyjnych z ciężkim OSA efektywna terapia stałym dodatnim ciśnieniem w drogach oddechowych (CPAP, continuous positive airway pressure) prowadzi do znaczącej redukcji częstości występowania MH [20].

Nadciśnienie tętnicze maskowane częściej występuje u pacjentów z przewlekłą chorobą nerek, u których jest obniżony szacunkowy współczynnik filtracjikłębuszkowej (eGFR, estimated glomerular filtration rate) i/lub występuje albuminuria czy jawny białkomocz. Wiąże się to z predyspozycją do wysokich wartości ciśnienia w nocy [8]. Zaobserwowano również częstsze występowanie MUCH, jest to szczególnie obciążające u pacjentów z krańcową niewydolnością nerek [21].

\section{GLOBALNE RYZYKO SERCOWO- -NACZYNIOWE ZWIAZZANE Z NADCIŚNIENIEM MASKOWANYM}

W przeciwieństwie do nadciśnienia białego fartucha, u pacjentów z MH globalne ryzyko sercowo-naczyniowe jest znamiennie wyższe w porównaniu z osobami normotensyjnymi [22] ze względu na częste występowanie powikłań narządowych 
i chorób współistniejących. Są to więc $\mathrm{z}$ reguły pacjenci wysokiego ryzyka $[16,23]$. Wykazano, że u pacjentów z MH, w porównaniu z osobami normotensyjnymi, częściej występują powikłania narządowe: przerost lewej komory, przyspieszenie fali tętna (PWV, pulse wave velocity), poszerzenie kompleksu błony wewnętrznej i środkowej (IMT, intima-media thickness) w tętnicy szyjnej, albuminuria [24, 25].

Nadciśnienie tętnicze maskowane wiąże się również ze zwiększonym ryzykiem wystąpienia incydentów sercowo-naczyniowych: zawału serca, udaru mózgu. Jest ono około 1,5-krotnie wyższe niż u osób normotensyjnych i prawie tak wysokie jak w utrwalonym nadciśnieniu tętniczym [23, 26]. U pacjentów z MH częściej pojawiają się powikłania nerkowe pod postacią CKD: zarówno zachorowania de novo, jak i pogorszenie przebiegu CKD obniżenie eGFR, nasilenie białkomoczu [8]. Źle kontrolowane nadciśnienie tętnicze maskowane, podobnie jak $\mathrm{MH}$ u chorych nieleczonych, niesie za sobą podwyższone ryzyko zdarzeń sercowo-naczyniowych, zwłaszcza u pacjentów ze współistniejącą cukrzycą czy CKD. Nadciśnienie tętnicze maskowane jest również czynnikiem ryzyka utrwalonego nadciśnienia tętniczego. Wśród pacjentów z rozpoznanym $\mathrm{MH}$ u $26 \%$ chorych po 3 latach i u $37 \%$ po 5 latach rozwinie się utrwalone nadciśnienie tętnicze. Około $20 \%$ chorych po 5 latach pozostanie z rozpoznaniem MH [27] (ryc. 1), co może potencjalnie opóźnić diagnozęi leczenie, a także doprowadzić do postępu rozwoju subklinicznych powikłań narządowych.

\section{LECZENIE}

Jakjuż wspomniano, MH niesie za sobą istotne zwiększenie ryzyka sercowo-naczyniowego i zwiększa praw-

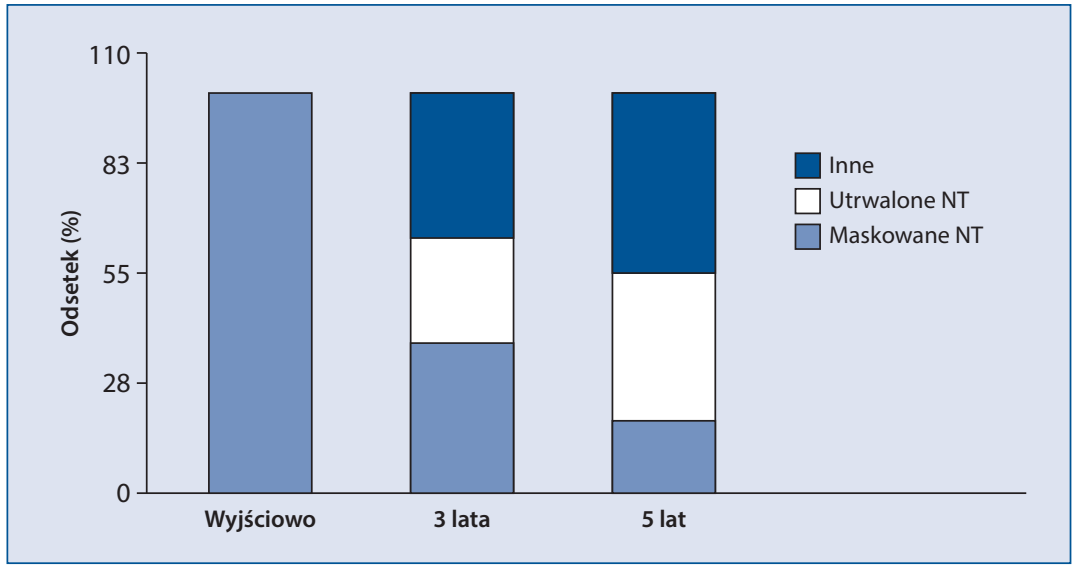

Rycina 1. Nadciśnienie tętnicze maskowane - ocena progresji w 5-letniej obserwacji (zmodyfikowano na podstawie [27]); NT —nadciśnienie tętnicze

dopodobieństwo wystąpienia chorób układu krążenia i nerek, które jest porównywalne do ryzyka w przebiegu utrwalonego nadciśnienia tętniczego [22]. Co więcej, u około $30 \%$ pacjentów z MH dojdzie do rozwinięcia się utrwalonego nadciśnienia tętniczego. Dlatego też należy aktywnie poszukiwać MH, zwłaszcza u pacjentów ze współistniejącymi powikłaniami narządowymi charakterystycznymi dla nadciśnienia tętniczego, nawet jeśli OBPM jest prawidłowe. Do rozpoznania $\mathrm{MH}$ niezbędne jest wykonanie pomiarów poza gabinetem lekarskim HBPM lub ABPM. W celu zdiagnozowania $\mathrm{MH}$ w nocy zaleca się wykonanie ABPM. Podczas podejmowania decyzji odnośnie do wdrożenia leczenia hipotensyjnego w MH zawsze powinna być brana pod uwage całość obrazu klinicznego. Należy rozważyć współistniejące czynniki ryzyka, ocenić zaburzenia metaboliczne i subkliniczne powikłania narządowe, choroby współistniejące - czyli określić globalne ryzyko sercowo-naczyniowe. Dopiero po ustaleniu rozpoznania i stratyfikacji ryzyka globalnego ryzyka sercowo-naczyniowego, zgodnie z wytycznymi ESH/ESC, należy wdrożyć leczenie hipotensyjne, zarówno niefarmako- logiczne, jak i farmakologiczne. Propozycję algorytmu diagnostyczno-terapeutycznego przedstawiono na rycinie 2.

Celem terapii jest zmniejszenie ryzyka wystąpienia powikłań sercowo-naczyniowych i nerkowych dzięki osiągnięciu dobrej kontroli ciśnienia w pomiarach pozagabinetowych, czyli średnie ciśnienie $\mathrm{w}$ pomiarach domowych i podczas dnia w ABPM o wartościach poniżej 135/85 mm Hg, z nocy zaś — poniżej 120/70 mm Hg.

Leczenie niefarmakologiczne obejmuje modyfikację stylu życia: włączenie wysiłku fizycznego i modyfikację diety w celu redukcji masy ciała, ograniczenie/zaprzestanie spożycia alkoholu i używek, zaprzestanie palenia tytoniu. Można rozważyć porady psychologiczne - dotyczące na przykład nauki radzenia sobie ze stresem. Aby jednak osiągnąć celleczenia, na ogół niezbędne jest jednoczasowe wprowadzenie farmakoterapii.

Strategia leczenia farmakologicznego nie różni się od zalecanej w terapii nadciśnienia tętniczego utrwalonego, pacjenci zazwyczaj wymagają stosowania kilku leków hipotensyjnych. Dlatego duży nacisk kładzie się na włączanie preparatów złożonych $[1,5]$. Trzeba zwrócić uwagę na 


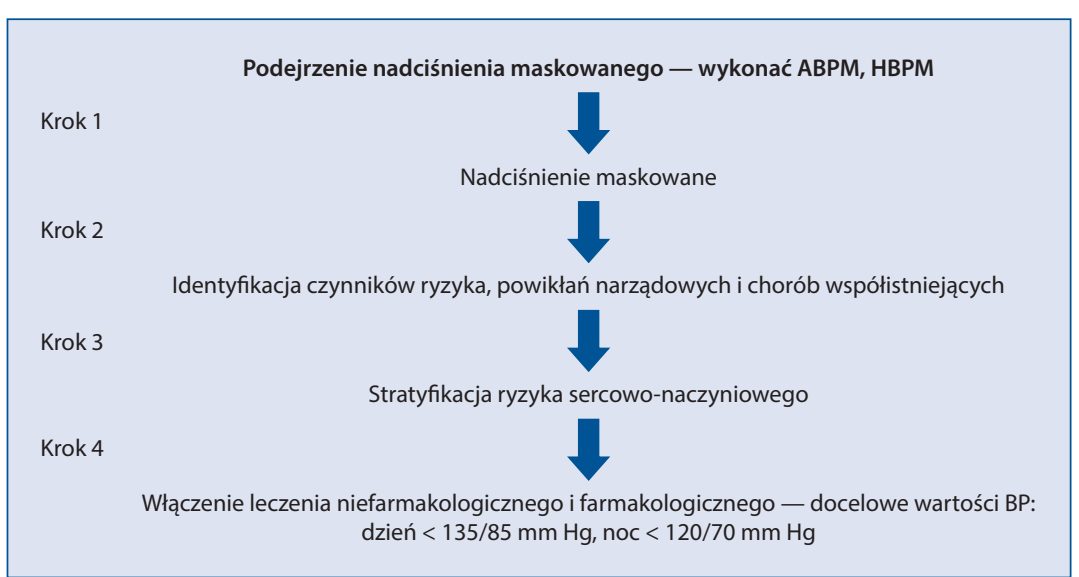

Rycina 2. Algorytm postępowania diagnostyczno-terapeutycznego w nadciśnieniu maskowanym; ABPM (ambulatory blood pressure measurement) - całodobowa rejestracja ciśnienia tętniczego; HBPM (home blood pressure measurement) - domowe pomiary ciśnienia tętniczego; BP (blood pressure) - ciśnienie tętnicze

chronoterapię leczenia - aby osiągnąć zalecaną kontrolę ciśnienia w godzinach snu, niezbędne może być podawanie leków w godzinach wieczornych, aby wymusić nocny spadek ciśnienia. Efekty zastosowanej terapii przeciwnadciśnieniowej powinny być oceniane w pomiarach pozagabinetowych HBPMi ABPM. Postępowanie terapeutyczne w MUCH nie różni się od tego $\mathrm{W} \mathrm{MH}$.

Niestety nadal brakuje dowodów na to, że strategia leczenia oparta na pomiarach pozagabinetowych przełoży się na zmniejszenie występowania powikłań narządowych, incydentów i zgonów sercowo-naczyniowych. Ze względu na znaczenie epidemiologiczne w populacji ogólnej i duże ryzyko powikłań, jakie niesie za sobą MH i MUCH, bez wątpienia konieczne są dalsze badania, aby ustalić jednoznaczne rekomendacje.

Być może w odpowiedzi na to pytanie pomoże toczące się badanie MASTER (MASked-unconTrolled hy$p$ ERtension management based on office BP or on ambulatory blood pressure measurement). Jest to prospektywne, randomizowane, otwarte badanie porównujące dwie strategie postępowa- nia na podstawie wartości ciśnienia tętniczego zmierzonych: 1) w gabinecie lekarskim (OBPM) lub 2) poza gabinetem lekarskim - ABPM u pacjentów z MUCH. Efekty tych dwóch strategii leczenia będą porównywane na podstawie oceny powikłań narządowych, przerostu lewej komory i mikroalbuminurii - $\mathrm{w}$ pierwszym roku trwania badania i po 4 latach — oraz częstości incydentów sercowo-naczyniowych w ciągu 4 lat [28].

\section{Podsumowanie}

Podsumowując, MH może dotyczyć $1 / 3$ pacjentów z wysokim prawidłowym ciśnieniem $\mathrm{w}$ gabinecie. Ze względu na związane z nim ryzyko sercowo-naczyniowe zarówno wśród pacjentów dotychczas nieleczonych, jak i tych z włączoną terapią hipotensyjną stanowi ono ważny problem kliniczny. Znaczna część tej grupy chorych rozwinie utrwalone nadciśnienie tętnicze. Nawet jeden na pięciu pacjentów przez wiele lat będzie miał podwyższone wartości ciśnienia tętniczego jedynie w pomiarach pozagabinetowych, co potencjalnie opóźni diagnozęi leczenie, a jednocześnie będzie postępował rozwój subklinicz- nych powikłań narządowych. Dlatego zgodnie z aktualnymi zaleceniami ESH/ESC należy aktywnie poszukiwać $\mathrm{MH}$, zaś ABPM i HBPM powinny być podstawowym elementem diagnostyki i kontroli nadciśnienia tętniczego.

\section{PIŚMIENNICTWO}

1. Williams B, Mancia G, Spiering W, et al. Authors/Task Force Members:, ESC Scientific Document Group . 2018 ESC/ESH Guidelines for the management of arterial hypertension. Eur Heart J. 2018; 39(33): 3021-3104, doi: 10.1093/eurheartj/ehy339, indexed in Pubmed: 30165516.

2. Booth JN, Diaz KM, Seals SR, et al. Masked hypertension and cardiovascular dsease events in a prospective cohort of blacks: the Jackson Heart Study. Hypertension. 2016; 68(2): 501-510, doi: 10.1161/HYPERTENSIONAHA.116.07553, indexed in Pubmed: 27354424

3. Mancia G, Verdecchia P. Clinical value of ambulatory blood pressure: evidence and limits. Circ Res. 2015; 116(6): 1034-1045, doi: 10.1161/CIRCRESAHA.116.303755, indexed in Pubmed: 25767288.

4. Anstey DE, Pugliese D, Abdalla M, et al. An update on masked hypertension. Curr Hypertens Rep. 2017; 19(12): 94 , doi: 10.1007/s11906-017-0792-4, indexed in Pubmed: 29071520.

5. Tykarski A, Narkiewicz K, Gaciong Z, et al. Zasady postępowania w nadciśnieniu tętniczym - 2015 rok. Wytyczne Polskiego Towarzystwa Nadciśnienia Tętniczego - wersja skrócona. Nadciśnienie Tętnicze w Praktyce. 2015(1): 1-70.

6. Gorostidi M, Vinyoles E, Banegas JR, et al. Prevalence of white-coat and masked hypertension in national and international registries. Hypertens Res. 2015; 38(1): 1-7, doi: 10.1038/hr.2014.149, indexed in Pubmed: 25319601

7. Peacock J, Diaz KM, Viera AJ, et al. Unmasking masked hypertension: prevalence, clinical implications, diagnosis, correlates and future directions. J Hum Hypertens. 2014; 28(9): 521-528, doi: 10.1038/jhh.2014.9, indexed in Pubmed: 24573133

8. Drawz PE, Alper AB, Anderson $\mathrm{AH}$, et al. Chronic Renal Insufficiency Cohort Study Investigators. Masked hypertension and elevated nighttime blood pressure in CKD: prevalence and association with target organ damage. Clin J Am Soc Nephrol. 2016; 11(4): 642-652, doi: 10.2215/CJN.08530815, indexed in Pubmed: 26912547

9. Muntner P, Einhorn PT, Cushman WC, et al. 2017 National Heart, Lung, and Blood Institute Working Group. Blood pressure 
assessment in adults in clinical practice and clinic-based research: JACC Scientific Expert Panel. J Am Coll Cardiol. 2019; 73(3): 317-335, doi: 10.1016/j.jacc.2018.10.069, indexed in Pubmed: 30678763

10. Alwan H, Pruijm M, Ponte B, et al. Epidemiology of masked and white-coat hypertension: the family-based SKIPOGH study. PLoS One. 2014; 9(3): e92522, doi: 10.1371/journal.pone.0092522, indexed in Pubmed: 24663506

11. Franklin SS, Thijs L, Li Y, et al. International Database on Ambulatory blood pressure in Relation to Cardiovascular Outcomes Investigators. Masked hypertension in diabetes mellitus: treatment implications for clinical practice. Hypertension. 2013; 61(5): 964-971, doi: 10.1161/HYPERTENSIONAHA.111.00289, indexed in Pubmed: 23478096.

12. Grassi G, Seravalle G, Dell'Oro R, et al. Reproducibility patterns of plasma norepinephrine and muscle sympathetic nerve traffic in human obesity. Nutr Metab Cardiovasc Dis. 2009; 19(7): 469-475, doi: 10.1016/j. numecd.2008.09.008, indexed in Pubmed: 19157817.

13. Cacciolati C, Tzourio C, Hanon O. Blood pressure variability in elderly persons with white-coat and masked hypertension compared to those with normotension and sustained hypertension. Am J Hypertens. 2013; 26(3): 367-372, doi: 10.1093/ajh/hps054, indexed in Pubmed: 23382487.

14. Yano Y, Bakris GL. Recognition and management of masked hypertension: a review and novel approach. J Am Soc Hypertens. 2013; 7(3): 244-252, doi: 10.1016/j. jash.2013.02.002, indexed in Pubmed: 23523411

15. Cloutier L, Lamarre-Cliche M. Hypertension in adults with type 2 diabetes: a review of blood pressure measurement methods, targets and therapy. Can J Diabetes.
2018; 42(2): 188-195, doi: 10.1016/j.jcjd. 2018.01.012, indexed in Pubmed: 29602406.

16. Mancia G, Bombelli M, Facchetti R, et al. Increased long-term risk of new-onset diabetes mellitus in white-coat and masked hypertension. J Hypertens. 2009; 27(8): 1672-1678, doi: 10.1097/hjh.0b013e32832be5f9.

17. Marrone O, Bonsignore MR. Blood-pressure variability in patients with obstructive sleep apnea: current perspectives. Nat Sci Sleep. 2018; 10: 229-242, doi: 10.2147/NSS. S148543, indexed in Pubmed: 30174467.

18. Drager LF, Diegues-Silva L, Diniz PM, et al. Obstructive sleep apnea, masked hypertension, and arterial stiffness in men. Am J Hypertens. 2010; 23(3): 249-254, doi: 10.1038/ajh.2009.246, indexed in Pubmed: 20019671

19. Baguet JP, Lévy P, Barone-Rochette $G$, et al. Masked hypertension in obstructive sleep apnea syndrome. J Hypertens. 2008; 26(5): 885-892, doi: 10.1097/HJH.0b013e3282f55049, indexed in Pubmed: 18398330

20. Drager LF, Pedrosa RP, Diniz PM, et al. The effects of continuous positive airway pressure on prehypertension and masked hypertension in men with severe obstructive sleep apnea. Hypertension. 2011; 57(3) : 549-555, doi: 10.1161/HYPERTENSIONAHA.110.165969, indexed in Pubmed: 21242462.

21. Agarwal R, Pappas MK, Sinha AD. Masked uncontrolled hypertension in CKD. J Am Soc Nephrol. 2016; 27(3): 924-932, doi: 10.1681/ASN.2015030243, indexed in Pubmed: 26163421

22. Banegas JR, Ruilope LM, de la Sierra A, et al. Relationship between clinic and ambulatory blood-pressure measurements and mortality. N Engl J Med. 2018; 378(16): 1509-1520, doi: 10.1056/NEJMoa1712231, indexed in Pubmed: 29669232.
23. Ohkubo T, Kikuya M, Metoki H, et al. Prognosis of "masked" hypertension and "white-coat" hypertension detected by 24-h ambulatory blood pressure monitoring 10-year follow-up from the Ohasama study. J Am Coll Cardiol. 2005; 46(3): 508-515, doi: 10.1016/j.jacc.2005.03.070, indexed in Pubmed: 16053966.

24. Kenny IE, Saeed S, Gerdts E, et al. Masked hypertension in obesity: potential predictors and arterial damage. Blood Press Monit. 2017; 22(1): 12-17, doi: 10.1097/MBP.0000000000000220, indexed in Pubmed: 27776078.

25. Hänninen MRA, Niiranen TJ, Puukka PJ, et al. Target organ damage and masked hypertension in the general population: the Finn-Home study. J Hypertens. 2013; 31 (6): 1136-1143, doi: 10.1097/HJH.0b013e$32835 \mathrm{fa} 5 \mathrm{dc}$, indexed in Pubmed: 23466942.

26. Brguljan-Hitij J, Thijs L, Li Y, et al. International Database on Ambulatory Blood Pressure in Relation to Cardiovascular Outcome Investigators. Risk stratification by ambulatory blood pressure monitoring across JNC classes of conventional blood pressure. Am J Hypertens. 2014; 27(7): 956-965, doi: 10.1093/ajh/hpu002, indexed in Pubmed: 24572704

27. Trudel X, Milot A, Brisson C. Persistence and progression of masked hypertension: a 5-year prospective study. Int J Hypertens. 2013; 2013: 836387, doi: $10.1155 / 2013 / 836387$, indexed in Pubmed: 24455208.

28. Parati G, Agabiti-Rosei E, Bakris GL, et al. MASked-unconTrolled hypERtension management based on office BP or on ambulatory blood pressure measurement (MASTER) Study: a randomised controlled trial protocol. BMJ Open. 2018; 8(12): e021038, doi: 10.1136/bmjopen-2017-021038, indexed in Pubmed: 30573476. 